doi: 10.14267/cojourn.2019v4n2a7

\title{
Why (and How) Rusyns Joined Czechoslovakia a \\ Hundred Years Ago
}

\author{
Sándor Seremet ${ }^{1}$
}

\begin{abstract}
It is soon to be 100 years since the modern Transcaprathian region of Ukraine (also known as Kárpátalja, as the Podkarpatska Rus and as the Zakarpattia Region) was incorporated into the new-born state of Czechoslovakia as per the treaty of Saint-Germain-en-Laye. Czechoslovakia was built by merging different ethnicities, one of which were the Rusyns who were promised substantial autonomy within the confines of their traditional ethnic lands. The present study examines the thoughts of the Rusyn leaders regarding their preferences of territorial belonging at the end of World War I, with due attention to the differences between various groups in Hungary and in the American diaspora. At the Paris Peace Conference, the Rusyns, as members of the Czechoslovak delegation, were aiming to gain fair borders for their nation, a task that was, however, complicated, to say the least. During the conference, the region became a source of numerous conflicts between the victors, and even within the Czechoslovak delegation itself. As a result, significant Rusyn minorities remained in Romania, Poland and Slovakia. In this particular case, geopolitical considerations prevailed over the principle of self-determination for a nation which the "New Europe" declared to be one of the key elements of the postwar world. The fact that the seceding parts of imperial states were often divided about what country to belong to and under which particular political elite is often overlooked in Western historiography. This study seeks to provide new insights into this relatively seldom-discussed case - and into the reasons and circumstances that led to the decisions taken at the Conference in regard to it.
\end{abstract}

\footnotetext{
${ }^{1}$ Born in Mukachevo, Ukraine, in 1988. Studies: Faculty of History at Uzhhorod National University (2005-2010, MA degree in 2010); Doctoral School of History of Pázmány Péter Catholic University in Budapest (2010-2013). Absolved in 2013. Worked as historian at The Institute of the Twentieth Century (Budapest) from January 2013 to September 2014. In the years 2014/2015 and 2015/2016, he was a fellow scholar at the Department of Czech History at Charles University in Prague, with the support of the Post Master Scholarship of the International Visegrad Fund. Defended his doctoral dissertation ("The formation of today's Transcarpathia's borders after World War I, 1918-1925") in May 2016.
} 
Keywords: Rusyns, Podkarpatska Rus, Czechoslovakia, self-determination, borders, territorial changes, minority rights, diplomacy

\section{Towards the Scranton Resolution}

After four years of war, in January 1919 in Paris, the Peace Conference started to work in order to shape the post-war world. One of the treaties of the Paris Peace conference was the one signed in Saint-Germain-en-Laye on September 10, 1919. As per the treaty, the Austro-Hungarian Monarchy dissolved and numerous independent states appeared on the map of Europe based on the right of the self-determination of nations. One of these new states was the Czechoslovak republic, which obtained for itself a territory that appeared in its diplomatic doctrine at the very end of the war - a terra incognita that previously had no geopolitical importance in Europe, yet became a source of conflicts between the victors: today's Transcarpathia.

The region we now refer to as the Transcarpathian region (of Ukraine), or as Subcarpathia $^{2}$ (Kárpátalja), or as Podkarpatska Rus (as it was named in Czechoslovakia), was not known as a clearly defined territorial unit at the time. It was formed from certain parts of the four counties in the Northeast of Hungary, namely, Ung, Bereg, Ugocsa and Máramaros, and was inhabited by a mixed population of Rusyns, Hungarians, Romanians, Slovaks, Jews, etc. The fact of the presence of several ethnic groups in the region turned it - the entire territory or certain parts of it - into an object of clashing aspirations for the waring nations.

The Russian Empire, for its part, declared at the beginning of the war that it intended to incorporate Galicia and Northern Hungary (the Hungarian Rus as they called it) into its own territory. They built their demand on the fact that Tsarist Russia considered the local population as Russians. The claim to legitimacy was based on the asserted need to unite the Slavic population in the same Empire.

Certain parts of the Northeastern counties fell into the sphere of interest of Romania. In the 19th century, almost one half of ethnic Romanians lived outside of Romania. With this fact in mind, Russia planned to gain support from Romania by offering it the region of Bukovina up to the river Prut, and Máramaros county to the south of the river Tisza.

\footnotetext{
${ }^{2}$ In English, Subcarpathia (Ukrainian Subcarpathia) is the most common contemporary term that refers to the Prykarpatia region on the northeastern side of the Carpathians in Ukraine. In this article, we use this term to denote the southern side of Carpathians.
} 
doi: 10.14267/cojourn.2019v4n2a7

Territorial offers were later also noted in the agreement signed by Romania and Russia in mid-summer 1916. One of the obligations for Romania stemming from this was that it would have to join the war by August 28, 1916 at the latest (Spector, 1962: 28-62).

The Russian plans collapsed due to the revolutionary events of 1917. Furthermore, centrifugal tendencies of war, revolution, and the peace imposed by Germany, resulted in the constituent nations of the empire seceding. After the revolution in February 1917, the Ukrainian National Council in Kyiv started to work on the creation of an autonomous district which would stay in a new, federal Russia. Later, after the Bolshevik coup, the autonomous People's Republic of Ukraine declared its independence on January 25, 1918, and signed a separate peace with Germany and Austria-Hungary. Russia, for its part, had to accept the independence of Ukraine according to the Treaty of Brest-Litovsk. Even so, Ukraine was eventually incorporated into the USSR in 1922. In Brest-Litovsk, however, some aspirations were already present to the effect of incorporating the Podkarpatska Rus to Ukraine, as it shared a border with the People's Republic of Western Ukraine. This state was established on November 9, 1918, within Austria-Hungary, and aimed to unite the Ukrainians of Galicia and Bukovyna (two Republics joined in one state on January 22, 1919.) It was quite logical within this framework to incorporate the Rusyns from the other side of the Carpathians into their state (Subtelnyj, 1992: 296-300).

Tomaš Garrigue Masaryk, the future president of Czechoslovakia, showed very few - if any - interest in the region. He was convinced that it will eventually be ceded to Russia. However, when Russia collapsed due to the revolution, he changed his mind. In 1917, he spent time in Kyiv, and recorded in his memoirs that he found during his trip that the leaders of the Ukrainian movement had nothing against the incorporation of the Rusyn lands into Czechoslovakia (Masaryk, 2005: 210). His then-formed intentions only took the shape of an formal diplomatic initiative by 1918, during his visit to the United States.

Back in Hungary, Rusyns of Hungarian background were not seriously interested in political questions, and had no common plans for their future up till the Aster revolution (October 31, 1918). The possibility of national self-determination then appeared on the international agenda. Differences among Rusyins arose over the preferences of the different regional groups of Rusyns. The Lemkos, located in the Western edge of today's Transcarpathian region, and on the Eastern edge of today's Slovakia, were adherents of the pro-Russian claims. They were represented by a Council based in today's Prešov (Eperjes, while in Hungary; part of Slovakia today). The Hutsuls of Máraramos, who 
doi: 10.14267/cojourn.2019v4n2a7

were in touch with the Rusyns of Eastern Galicia, were sympathizing in their political beliefs with the radical Ukrainian doctrine. The third group, the Boykos were mostly apolitical, and had no interest in the political machinations of that time. But the Greek Catholic clergy, the major site of the spiritual life of the community, as well as their small intelligentsia, had a more distinctive orientation towards the traditional Hungarian state. Their organization was based in Uzhhorod (Hanak 1998, 9-10).

Due to the limits of the present study, the actions of the Rusyn organizations in Hungary will not be examined. However, we have to state that once the territory of today's Slovakia was taken over by the Czechoslovak forces in December 1918, the previously pro-Russian council of Prešov changed its orientation towards Prague. Similar shifts took place in the council of Uzhhorod in Janurary 1919, after the city was occupied by the Czechoslovak army.

Meanwhile, in Paris, on January 18, 1919, the Paris Peace Conference was inaugurated. Czechoslovak diplomacy gained significant successes in the international arena. By that time, it was clear that the Rusyn question would be closed by the annexation of the territory by Czechoslovakia. Neighboring Romania and Poland, in spite of their interest in certain parts of the region, could not really thwart the Czechoslovak intentions. Poland declared that it did not claim any territories to the south from the Carpathians except some minor areas near today's Stara Lubovna. Romania was still hoping that Subcarpathia would be taken by Russia, which would in turn give it control of the territories up to the River Tisza, according to the agreement of 1916 cited above. Diplomats from Kyiv and Stanislav (i.e., representatives of the People's Republic of Ukraine and the People's Republic of Western Ukraine) and their claims were not taken seriously. Ukraine as a state was considered unviable. Hungary was a defeated country, and thus the Hungarian claims were not taken into consideration, either. The Russian scenario was likewise implausible as uncertainties regarding the outcome of the civil war and the rejection of the Bolshevik regime led the Entente to rule out giving the Rusyn territories to Russia (Magocsi, 1998: 62). This made it clear that the Rusyn lands would be ceded to Czechoslovakia, as the Czechoslovak diplomats could prove their claims were supported by the Rusyn organizations in Hungary as well as in the United States. As mentioned above, certain Rusyn councils actually changed their ideas mid-stream, only thus, eventually, orientating towards Czechoslovakia. The pioneers of support for the Czechoslovak option were the Rusyn emigrant communities in the U.S. who had some indirect political influence. 
doi: 10.14267/cojourn.2019v4n2a7

The Rusyn immigrant community in the U.S. was not well-organized politically, and had no uniform views regarding the future of their homeland. Among a certain group of those Rusyn leaders, the first idea to emerge was a certain union with Russia (conforming to the plans of Russia aiming at the incorporation of Galicia, which would have created a shared border with Rusyns to the south from the Carpathians). Despite this, they ultimately played an essential role in the process of the incorporation of today's Transcarpathia into Czechoslovakia.

In 1917, Pjotr Hatalak (1885-1949), a pro-Russian activist of Galician origin, sought to assemble a Russian ${ }^{3}$ congress of the representatives of Galicia, Bukovyna and the Hungarian Rus $^{4}$ (represented by Nicholas Pachuta). This congress sent a memorandum to the All-Russian Constituent Assembly which declared that the Rusyns are willing to join democratic Russia with all of their ethnic territories (Hatalák, 1936: $12-13)$.

Representatives of the Greek Catholic Church, which gathered the majority of Rusyns living in the U.S., were opposing the statements of the Russian congress and declared that Rusyn citizens of Hungary after the end of the war should remain within the confines of the Hungarian state, with broad autonomies provided (Pop, 2005: 274). The Bolshevik coup then undermined the pro-Russian wing of the U.S.-based Rusyns diaspora.

As the circumstances changed, Pachuta decided to build contacts with the American Slovak League instead. The League was engaged in negotiations with Czech organizations regarding the union of Czechs and Slovaks in one state, within which Slovakia would gain autonomy (Rychlík - Rychlíková, 2013: 19.).

In May 1918, T. G. Masaryk arrived in the United States. Thanks to his wife, Charlotte Garrigue, he already had good relations with the U.S. government, especially with Secretary of State Robert Lansing, and thus to the White House. President Woodrow Wilson and Masaryk agreed on many things regarding the post-war world settlement, but while Wilson aimed to reform Austria-Hungary, Masaryk wished to liberate the Czechs and Slovaks from under its rule. The success of Masaryk in the U.S. had been augmented by Adolf Joachim Sabath, a U.S. congressman with Czech (or possibly Slovak) ethnic

\footnotetext{
${ }^{3}$ In Hungary, the Rusyns were called “orosz” (Russian), besides “ruszin” (Rusyn) and "rutén” (Ruthene). "Orosz" comes in this context from Russkij/Rusyn ("Russian", i.e. inhabitant of the Rus), and not necessarily from Rossijskij (Russian, i.e. a citizen of, or one who belongs to, Russia).

${ }^{4}$ This term was often used at the beginning of the 20th century. Even in the Czech documents one can find references to „Uherská Rus”.
} 
doi: 10.14267/cojourn.2019v4n2a7

roots. Sabath discussed the question of the liberation of the Czech lands in the U.S. Congress on May 5, 1917. Back then, the dissolution of Austria-Hungary was not even part of the discourse among the Entente powers. Furthermore, on several occasions, he had joined Wilson's entourage on trips abroad, during which he informed the president about the actions of Masaryk and pressed the U.S. administration not to conclude a separate peace with the Austrian-Hungarian Monarchy (Hořec, 1999: 5-7).

The previously mentioned Czech-Slovak negotiations led to the signing of the Pittsburgh Agreement ${ }^{5}$ on May 30, 1918. Masaryk himself visited the official event. Pachuta was in Pittsburgh as well, so he met Masaryk and handed over a memorandum issued by the Narodna Obrana (National Self-defense, a previously pro-Russian Rusyn organization in the U.S.), which declared the union of the entire Carpatho-Russian (Rusyn) nation with the Czechoslovak state on the basis of self-governance (AÚTGM R. PR, K400, S1). This memorandum had been previously sent to Robert Lansing in April 1919 (Magocsi, 1998: 54).

On July 23, 1918, the Rusyn ecclesial and secular organizations were united in the “American National Council of Uhro-Rusinians" (ANRUR). The Council announced the possible solutions of the Rusyn question: autonomy within Hungary, to be preferred; if that would not be possible: join the Ukrainians of Galicia and Bukovina; if that would prove similarly impossible, join another state, but on the basis of autonomy and the protection of their national entity (Pop, 2005: 274-275). In September 1918, the leader of the ANRUR became a young lawyer, Gregory Zhatkovych, who was entrusted to work on a memorandum which had to be presented to President Wilson, to negotiate on the basis of this. Zhatkovych presented the memorandum on October 21, 1918, with the above-mentioned position outlined in it.

During the audience, Wilson explained that the first two options were barely plausible, as they would not be supported by the Entente. He suggested to seek autonomy within another state (Zhatkovych, 1921: 3). In this matter, Zhatkovych should therefore consult with Masaryk, who will participate at a conference in Philadelphia on October 23. Zhatkovych then contacted Masaryk and informed him about his meeting with the president and registered to participate at the conference of Central European nations in Philadelphia (Hořec, 1999:8-9).

\footnotetext{
${ }^{5}$ The Pittsburgh Agreement was a memorandum of understanding completed on May 31, 1918, between members of the Czech and Slovak expatriate communities in the United States of America. The agreement prescribed the intent of the co-signatories to create an independent Czechoslovakia.
} 
doi: 10.14267/cojourn.2019v4n2a7

Masaryk met Zhatkovych and the other five members of ANRUR on October 25. The main topic was the federative union of the Rusyns with Czechoslovakia. When representatives of the ANRUR asked Masaryk's opinion regarding the case, he stated: „If the Rusyns decide to join the Czechoslovak Republic, they will have a fully autonomous state". Zhatkovych also asked about the boundaries of the Rusyn lands, especially the one that would divide them from the Slovaks. Masaryk answered thus: „The borders will be designated in such a way that the Rusyns be satisfied" (Zhatkovych, 1921: 4-5)

Zhatkovych reported to the ANRUR regarding his negotiations with Wilson and Masaryk on the 29th of October. He, however, did not support the union with Czechoslovakia in public (Magocsi, 1998: 56). The final decision was adopted on November 12, 1918 in Scranton, ${ }^{6}$ at the assembly of ANRUR. A copy of the Scranton resolution was sent to Masaryk the next day. He showed his appreciation, but also warned Zhatkovych that it is only a declaration of a certain council, and that the peace conference might also point this out later on. So they started to discuss a plebiscite as an option, which later took place in the U.S., organized by Zhatkovych (Zhatkovych, 1921: 6).

The plebiscite took place in December 1918. According to the results, as many as $67 \%$ voted for the union with Czechoslovakia. The results of the plebiscite were sent to the Czechoslovak government and the U.S. Department of State (Danko, 2000: 142).

\section{Follow-up in Paris and Uzhorod}

Thus, by the end of 1918, Masaryk obtained the support of the Rusyn emigration, supported by numerous memoranda and a plebiscite. However, in order to avoid any accusations that the Rusyn land is to be ceded to the Czechoslovak state only on the basis of the leanings of overseas emigrant communities, it was important to convince the local Rusyn councils about the advantages of joining Czechoslovakia. Even though the council of Prešov and some leaders of other regional councils had already declared their willingness to unite with Czechoslovakia, there were no joint statements nor any common opinions on their side. This was an outstanding issue to be settled before proceeding. The Czechoslovak delegation in Paris included both Rusyn delegates from the USA and Rusyns from Hungary. On February 13, 1919, Zhatkovych arrived in Paris armed with the Scranton Resolution and the results of the plebiscite. In Paris, they met with Anton

\footnotetext{
${ }^{6}$ Scranton is the sixth largest city of the Commonwealth of Pennsylvania. Rusyn immigration of the late19th century largely targeted coal-mining regions, especially the southern part of New York State, Western Pennsylvania (around Pittsburgh), and mostly northeast Pennsylvania int he vicinity of Scranton.
} 
doi: 10.14267/cojourn.2019v4n2a7

Beskid, head of the council of Prešov, and together they set out to work as a board. They decided to add the memorandums issued by those Rusyn councils which were willing to join Czechoslovakia (Zhatkovych, 1921: 7). This package of documents was delivered to the conference together with the Czechoslovak aide-memoires on the 10th and 11th of March. The Rusyn question was described in "Memoire 6", assessing the situation as follows:

- Rusyns of Hungary are a nation that is very close to the Slovaks, they live together in a tight bond and among similar circumstances. Based on this fact, the union with the Czechoslovak Republic would not be problematic.

- This decision fits closest to the existing political realities and would be the most legitimate among those involved. This is the direction that Rusyns of the Hungarian state should likewise follow.

- Some of the Rusyns of Hungary already decided to join Czechoslovakia (ANM, Memoire 6: 9).

By the intervention of Edvard Beneš, Minister of Foreign Affairs of Czechoslovakia, the Rusyn board received an audience from the U.S. delegation and later with the head of the Council of Ten, on the $17^{\text {th }}$ and the $24^{\text {th }}$ of February, respectively. Zhatkovych suggested the Czechoslovak-Rusyn federation as the best solution of the Rusyn question and handed over the copies of the documents that contained all the necessary information (ANM, Memoire 6: 9). The offers of Zhatkovych's team were presented to the Council of Five, which took a positive decision regarding them. The Rusyn delegation was informed of the outcome on March 3. The following day, the American part of the Rusyn delegation left Paris and headed to Prague, to negotiate with Masaryk. Then they travelled to Subcarpathia. The main goal was to convince the councils to come up with a united conception regarding the future of the region, aiming at union with Czechoslovakia. Finally, these councils merged in a single body in Uzhhorod, named the Central National Council of Rusyns, on May 8, 1919 - this body declared that the Rusyns were willing to join Czechoslovakia. Alongside this resolution, a so-called "14 Points" were issued by the Council. They contained the expectations of the Rusyns regarding the organization of their state within Czechoslovakia and their territorial claims so that no Rusyn community shall live as a minority in other states. By this stage, the Czechoslovak delegation thus gained the declarations of support from the Rusyns both in emigration and in Hungary. Once the will of the Rusyns was declared, the summer months were dedicated to further negotiations regarding the borders of the - 
doi: 10.14267/cojourn.2019v4n2a7

politically - new-born region. Among the territorial questions, the major issues were the fate of Sighetu Marmației (Máramarosziget), then already under Romanian rule, but coveted by the Rusyns themselves, and the annexation of the so-called Lemko land in Eastern Galicia, which by that time was taken over by the Polish forces, and finally, the border that was to separate the lands of Slovaks and Rusyns (AKPR, Podkarpatska Rus I, III/17 inv. č 59).

These problematic issues were destined to be left unresolved. As for the proposed boundaries of the Rusyn region to be incorporated into Czechoslovakia, a significant Hungarian minority was resident in those areas, while a significant Rusyn minority outside of it - approximately 100,000 in Romania, and 200,000 in Slovakia and parts of Poland. Even though the Rusyn delegation in Paris as well as the Rusyn national councils of the region and the overseas communities invested enormous effort in the negotiations with the Czechoslovak delegation (and later with Czechoslovak government) to acquire these territories, they never succeeded in reaching that goal. Czechoslovakia never fought to gain territories for a Rusyn part of the country as it did for territories to be added to the Czech and Slovak constituent parts of that new-born republic. In Podkarpatska Rus, there was a low-intensity conflict over the territorial questions - with the Kingdom of Romania. This one, however, focused on railway connections and other economic issues, rather than on territories or boundaries per se.

As was demonstrated, according to the above, in the particular case of Subcarpathia, later the Podkarpatska Rus, the principles of self-determination were fulfilled only partially. On the one hand, the territory of Podkarpatska Rus was annexed to Czechoslovakia based on a plebiscite among the Rusyn emigrants in the USA and on the declaration of the joint Rusyn Council in Uzhhorod. On the other hand, considerations of geopolitical interest and high politics also play a major role in the events.

Jules Cambon, head of the territorial committee responsible for the Czechoslovak question, was working to achieve the best conditions for France. The goal was to provide as many strategically important territories to Poland and Czechoslovakia as possible, so they become part of an efficient buffer that can counterbalance Germany as well as Soviet-Russia ruled by the Bolsheviks (Magocsi, 1998: 63). Cambon also pointed out the importance of encircling and isolating the Kingdom of Hungary. In this matter, the future Podkarpatska Rus was critical, as it provided for a strategic link between Czechoslovakia and Romania (Pop, 2005: 293). 
doi: 10.14267/cojourn.2019v4n2a7

From the perspective of Czechoslovakia itself, the Rusyn issue was rather an opportunity than a political goal. Czech leaders had been considering to gain certain predominantly Rusyn territories from the outset, but incorporating the entire region was never really in their minds. Proceeding along these lines had certain advantages. Future Czechoslovakia planned to build tight economic relations with Russia. In case Russia gained Galicia, Rusyn territories would provide the necessary connection with the eastern neighbor, thus facilitating trade (Magocsi, 1998: 54). If Russia's plans were to come to naught, the region would still provide for a connection with Romania. Tellingly, Jiři Cisař, Masaryk's secretary at the time, assessed the Rusyn issue as follows:

„They [the Rusyns] are very important for us: at the conference in Philadelphia the emigrants from the Hungarian Rus represented by Zhatkovych decided to unite their territory with Czechoslovakia. They were ready to state it even at the peace conference. Due to this, they are allowed to achieve self-government for their nation while we gain the critically important connection with Romania." (Quoted in Vanat, 1979: 46.)

\section{Conclusion}

So why did the Rusyns join Czechoslovakia? As outlined in this article, viewed under the political circumstances prevailing at the time, Czechoslovakia seemed to be the most reasonable choice: a newborn state formed of Slavic nations of the former AustroHungarian Empire, pledging to operate on the basis of the principles of democracy and self-government for its constituent parts. Leading members of the Rusyn emigration were content with such a scenario based on the negotiations and the agreements reached.

The intricacies of the regional situation went far beyond the question of selfdetermination, or the will of a nation which had never before had a nation-state or a strictly defined political doctrine as such. The Paris Peace Conference and the leaders of the Czechoslovak movement had, however, another interest at stake: in shaping their new state, they had to keep in mind the strategic and economic considerations of the leading powers of the Conference, such as the need to establish a territorial connection with Romania, for example. Many times the principles of national self-determination were used, unfortunately, to justify the military and economic plans of the major powers, securing their interests. Nevertheless, as a result of the Peace Conference, the majority of Rusyns were united in the framework of a single territorial unit, named Podkarpatska Rus, as part of the Republic of Czechoslovakia. In the new state, Rusyns were not considered 
doi: 10.14267/cojourn.2019v4n2a7

a minority - they had their official language, press, education, as well as their own political parties and movements.

As may be concluded, it is not easy to please all parties and interests without harming anyone even if the stakeholders are on the same side. This was one of the lessons which the Rusyns learned at the peace conference that concluded World War I onehundred years ago.

The story of the Rusyn lands is an often overlooked case in the context of the territorial re-ordering of Europe that took place after World War I. However, its significance goes beyond the direct repercussions for the Rusyns. The outcome raises important questions as to the principle of self-determination: What exactly constitutes a nation that has the right to lay claim to a national territory? What are the prerequisites to be recognized as a nation in the international field? And, most of all, what are the limits of self-determination?

The case also underlines the fact that the post-war territorial re-ordering of Europe did not merely adjust international boundaries to the existing political realities but at times the Conference itself created new political realities based on the redefinition of state structures and the very concepts of nation and territory.

\section{References}

\section{Primary sources}

Archív Kancelař Presidenta Republiky (AKPR): Podkarpatska Rus I, III/17 inv. č 59.

Zpráva o audiencii Rusínské deputace u Presidenta dne 23. V. 1919.

Archív Narodího Múzea, Praha ANM: Fond Antonín Hajn K. č. 216. 5887. Memorie №6

Archív Ústavu TGM (AÚTGM) Praha - fond TGM R Podkarpatská Rus Krabice 400. Složka1. 1919. - Memorandum Amerikanskoj Russkoj Narodnoj Obrany posvjaščajemyj Jeho Vysokoblahorodiu Professoru T. G. Masaryk, slavnomu i nepohnutel'nomu truženiku za osvoboždenie Slavjanskich Narodov.

\section{Memoires}

Hatalák, Petr: Jak vznikla myšlenka připojiti Podkarpkatskou Rus k Československu. Štátní Tiskárna, Užhorod, 1935. 38. p.

Zsatkovych, G. I.: Expose. „Rusin Information Bureau” printed by „Am. Russky Viestnik" Homestead, 1921. 25. p. 
doi: 10.14267/cojourn.2019v4n2a7

Masaryk, Tomaš Garrigue: Svetová Revoluce II. Ústav Tomaše Garrigue Masaryka Praha, 2008. 357. p.

\section{Monographs, articles}

Danko, Iosyp: Ukrajinskij holos u plebistsyti 1918. roku v SSHA.//Kalendar Prosvity na 2000. rik. (Йосип Данко: Український голос у плебісциті 1918 року в США) // Календар «Просвіти» на 2000 р.. Просвіта. Ужгород 2000.

Hanak, Walter K.: Podkarpatsko-Rusínská otázka: 1918-1945. Praha 1998. 51. p.

Hořec Jaromír: První Kroky Svobody (Podkarpatská Rus 1918-1939) Edice Podkarpatská Rus, Praha, 1999, 90. 345. p.

Magocsi, Pavlo Robert: Formuvannia Natsionaljnoi Samosvidomostji: Pidkarpatska Rus (1848-1948) Uzhorod, 1994. 295 p.

Orest Subtelnyj - Istoriya: Ukraina. Kyiv, Lybid (Орест Субтельний Україна Історія. Київ Либідь). 1992. 592 р.

Pop, Ivan: Dějiny Podkarpatské Rusi v datech. Libri Praha 2005. 534 p.

Rychlík Jan - Rychlíková Magdaléna: Hospodařský, sociální, kulturní a politický vývoj Podkarpatské Rusi 1919-1939. Národohospodářský ústav Josefa Hlávky, Praha. 2013. 183. p.

Spector, Sherman D.: Rumania at the Paris Peace Conference. Bookman Associates, INC. New York, 1962.

Vanat, Ivan: Narysy Novitnioi Istorii Ukraintsiv Skhidnoi Slovatchyny. I. (1918-1938). 1990. (Нариси Новітньої Історії Укаїнців Східної Словаччини). Prešov, 1979. $410 \mathrm{p}$. 